\title{
Motor Symptoms and Schizophrenia
}

\author{
Sebastian Walther Werner Strik \\ University Hospital of Psychiatry, Bern, Switzerland
}

\section{Key Words}

Catatonia - Involuntary movements $\cdot$ Neuroimaging •

Neurological soft signs $\cdot$ Parkinsonism $\cdot$ White matter

\begin{abstract}
Classical schizophrenia literature reports motor symptoms as characteristic of the disorder. After the introduction of neuroleptic drugs, the existence of genuine motor disorders was challenged. Renewed interest arose as symptoms were found in never-medicated patients. Reports focused on abnormal involuntary movements, parkinsonism, neurological soft signs, catatonia, negative symptoms, or psychomotor slowing. Since these syndromes refer to different concepts, however, the definitions are not congruent and the symptoms overlap. The prevalence rates of motor symptoms in schizophrenia are surprisingly high, and recent studies indicate a possible pathobiology. In particular, the development and maturation of the human motor system appears to be closely linked to the emergence of motor symptoms observed in schizophrenia. Post-mortem and neuroimaging results demonstrated aberrant structure and function of premotor and motor cortices, basal ganglia, thalamus, and the connecting white matter tracts. Animal models have focused on aberrant neurotransmission and genetic contributions. Findings of localized abnormal oligodendrocyte function and myelination point to the special role of the white
\end{abstract}

matter in schizophrenia, and recent studies specifically found an association between motor abnormalities and white matter structure in schizophrenia. This review of the literature supports the idea that motor symptoms are closely related to the neurodevelopmental disturbances of schizophrenia and a distinct syndromal dimension with its own pathophysiology.

Copyright $\odot 2012$ S. Karger AG, Basel

\section{Introduction}

Altered motor behavior has consistently been reported in the classic schizophrenia literature [1-5]. Early schizophrenia investigators acknowledged a wide range of motor symptoms to be associated with the disorder. These comprehensive clinical descriptions were later widely neglected when scientific attention shifted to treatment-related motor symptoms.

Recent reviews have addressed the nosological problems concerning catatonia [6-8], the meaning of abnormal involuntary movements and neurological soft signs (NSS) in schizophrenia [9-11], psychomotor slowing [12], and motor deficits or neurological abnormalities in antipsychotic naïve schizophrenia patients $[10,13,14]$. Since these reviews focused on specific aspects of motor deficits or on special populations, a comprehensive view of motor

Sebastian Walther, MD

University Hospital of Psychiatry

Bolligenstrasse 111

CH-3000 Bern 60 (Switzerland)

Tel. +41 31930 9111, E-Mail walther@ puk.unibe.ch 
phenomena is difficult to develop, since the descriptions, definitions, and interpretations vary largely with the conceptual frameworks [15]. The current literature shows that there are several distinct, but largely overlapping concepts of motor disorders that are based on substantially diverse assumptions about their pathophysiology.

This selective review focuses on the signs and neurobiology of motor disorders in schizophrenia without a priori assumptions about their putative nature or nosological meaning. After an outline of the historical descriptions of motor symptoms, we will provide an overview of current concepts, as well as of the epidemiological and neurobiological evidence. Finally, we will review the possibility that disorders of the motor loop are the underlying cause of motor symptoms in schizophrenia.

\section{History}

Case notes from a 19th century asylum in England included descriptions of a variety of motor symptoms that today resemble catatonia, abnormal involuntary movements, or parkinsonism [16]. Lacking our modern concepts of motor syndromes in schizophrenia, the notes were descriptive, reporting, 'grimaces, fidgets, jerkiness, and twitching', gesticulating, rigidity, staring, and mutism.

In 1874, Kahlbaum [2] described a series of cases with predominant motor symptoms which he termed catatonia. Later, Kraepelin [17] integrated a syndrome of specific, persistent motor symptoms as the catatonic subtype in dementia praecox [8]. He noted, however, that catatonic symptoms such as negativism, mannerisms, grimacing, stereotypies, and echophenomena also occurred in other subtypes [5, 18]. Bleuler [1] noted several motor symptoms, including irregular muscular contractions, muscle fibrillations of the face, tremor, diminished arm swing during gait, and apraxia-like symptoms, as well as the catatonic symptoms described by Kahlbaum [2]. Bleuler [1] estimated that more than $50 \%$ of schizophrenia patients present with either persistent or recurrent catatonic symptoms. In his conceptualization, however, he did not consider catatonia a basic phenomenon, but rather an accessory, nonspecific symptom of schizophrenia [1]. Later, with the increasing influence of phenomenological psychopathology, diagnostic and pathogenetic concepts of schizophrenia focused on cognitive symptoms, including delusions, hallucinations, and disorders of self-perception. These symptoms were considered to be primary phenomena, while motor and emo- tional symptoms were interpreted as secondary phenomena for diagnosis [19-21]. During this period, detailed descriptions of a diversity of motor symptoms with a neuropathological understanding of the phenomena, including specific symptom patterns, outcomes, and inheritance, can be found only in the work of less influential authors $[3,4]$.

After the introduction of antipsychotic pharmacology, the intricate differential diagnosis between extrapyramidal side effects and intrinsic motor symptoms further challenged the understanding of the syndrome $[15,22]$. At one point, motor symptoms occurring in schizophrenia were attributed exclusively to antipsychotic treatment effects $[23,24]$, even though extrapyramidal symptoms had been reported in the preneuroleptic era $[25,26]$

Neurological signs in schizophrenia have been investigated since the 1970s [22, 27-29]. In the 1980s, neurological signs were interpreted as an expression of the neurobiology of schizophrenia and have received consistent attention since $[9,30]$. During this time, however, researchers regained interest in spontaneous movement disorders in schizophrenia, and rare populations of never-medicated patients were investigated [15, 31-33].

\section{Clinical Perspectives}

At least one motor sign has been reported to be prevalent in $66 \%$ of first-episode, never-medicated patients [34], in $59 \%$ of patients on admission [35], and in $80 \%$ of chronically medicated patients [36]. After a brief description of the conceptual overlaps, the following sections will introduce the main motor signs and the available prevalence rates (table 1). A short list of available assessment tools for motor symptoms in schizophrenia is appended in the online supplementary table 1 (for all online suppl. material, see www.karger.com/doi/10.1159/000339456).

\section{Conceptual Overlap}

A considerable proportion of patients presents with more than one motor phenomenon [34, 35, 37-39]. Today, it is impossible to determine whether the co-occurrence of various motor symptoms is due to lack of conceptual clarity, a strong intercorrelation, or a common neuronal basis. Furthermore, different investigators may pose different names for the same symptom. Rogers [15] preferred avoiding theory-laden terms and, in 1985, proposed the problem as a 'conflict of paradigms'. Symptom definitions in the current rating scales are still confusing and overlapping. Depending on the underlying concepts, re- 
Table 1. Prevalence rates of motor symptoms in schizophrenia patients

\begin{tabular}{|c|c|c|c|c|}
\hline & $\begin{array}{l}\text { First episode } \\
\text { medication naïve }\end{array}$ & $\begin{array}{l}\text { First episode } \\
\text { medicated }\end{array}$ & $\begin{array}{l}\text { Chronic } \\
\text { medication naïve }\end{array}$ & $\begin{array}{l}\text { Chronically } \\
\text { medicated }\end{array}$ \\
\hline NSS (>1 symptom) & $78-97 \%[51,94]$ & $48-100 \%[95,96]$ & $23 \%[97]$ & $39-98 \%[52,98]$ \\
\hline Dyskinesia & $12-13 \%[34,99]$ & $3 \%[57]$ & $35-51 \%[33,76]$ & $29-100 \%[38,56,100]$ \\
\hline Parkinsonism & $18-27 \%[34,75,99]$ & $34-43 \%[57,73,101]$ & $15 \%[76]$ & $23-55 \%[37,38]$ \\
\hline Catatonic symptoms ( $\geq 2$ signs) & $17 \%[67]$ & $5 \%[57]$ & no data available & $10-32 \%[49,70]$ \\
\hline
\end{tabular}

duced movement can be referred to as stupor, bradykinesia, or avolition [40]. Involuntary movements can be described as parakinesia or dyskinesia; involuntary face movements, grimacing, tics, or mannerisms [11, 15]. Likewise, rigidity is considered a sign of both parkinsonism and catatonia [41-43]. Rating scales for NSS include items that are also present in scales for parkinsonism or dyskinesia: rigor, tremor, adventitious overflow, or poor balance [9]. Likewise, most catatonia scales include rigor $[8,44]$.

In both chronic and first-episode schizophrenia patients, dyskinesia and parkinsonism can co-occur [34,35, 37-39, 44-46]. In order to disentangle motor symptoms, factor-analytic studies have been performed [34, 35]. Parkinsonism and retarded catatonia are highly intercorrelated [40, 47,48], and the factor 'positive catatonia' is correlated with dyskinesia [34, 48]. Furthermore, negative symptoms are highly correlated with catatonia ratings, NSS, dyskinesia, and parkinsonism [11, 35, 39, 40, 49, 50]. In addition, NSS are associated with dyskinesia and parkinsonism [51, 52], as well as with cognitive function [50]. Finally, psychomotor slowing seems to be related to catatonic symptoms $[50,53]$.

\section{Involuntary Movements}

Abnormal, involuntary movements in schizophrenia have been extensively reviewed $[10,11,13,54]$. Spontaneous and tardive dyskinesias (TD) comprise abnormal, involuntary, repetitive movements of the orofacial, limb, trunk, and respiratory musculature [54]. Prevalence rates indicate that abnormal, involuntary movements occur throughout the course of the disease (table 1), and are more prevalent with increasing age, approaching $100 \%$ in the elderly $[55,56]$. Antipsychotic medication improved dyskinesia in previously medication-naïve patients [57]. However, the clinical distinction between spontaneous and drug-induced dyskinesia is difficult to discern, and in chronic patients, the rate of drug-induced dyskinesia is supposed to prevail [55].

Motor Symptoms and Schizophrenia
A recent meta-analysis calculated an odds ratio of 3.59 for spontaneous dyskinesia in schizophrenia [58]. However, a large negative study $(\mathrm{n}=908)$ of Southeast Asian drug-naïve, first-episode schizophrenia subjects was not included in the meta-analysis [59]. The negative finding in Southeast Asians suggests an ethnicity effect [59]. In addition, spontaneous abnormal movements were reported in schizophrenia spectrum disorders and prodromal states [60-63], suggesting that the vulnerability for schizophrenia was associated with these movement disorders $[11,62]$.

\section{Neurological Signs}

NSS refer to neurological abnormalities in the domains of coordination, sensory integration, and sequential motor acts $[9,30]$. Specific motor signs assessed, e.g. gait, balance, finger-thumb opposition, dysdiadochokinesia, finger-to-nose test, fist-edge-palm test, fist-ring test and Ozeretski test NSS, tend to be stable over time [9, 30]. Indeed, NSS are prevalent in early stages (table 1), sometimes associated with psychopathology, and independent of medication; they may be ameliorated by antipsychotic treatment $[9,11,30]$. NSS are also found in schizophrenia spectrum disorders [64].

\section{Catatonic Symptoms}

Catatonia is a syndrome of abnormal motor behavior, but also includes impaired volition and affect. Clinical definitions are inconsistent and up to 40 symptoms have been described as catatonic $[8,41,65]$. A variety of rating scales have been published, but there are unresolved questions concerning inconsistent item and syndrome definitions and syndrome thresholds [8]. Pure motor signs include posturing, mannerisms, immobility, rigor, stereotypies, catalepsy, grimacing, and waxy flexibility. Signs associated with volition include automatic obedience, negativism, refusal to eat, withdrawal, and ambitendency. Furthermore, signs suggest an inability to suppress complex motor activities that are either self-initiat- 
ed (rituals or stereotypies) or induced (echophenomena) [66]. Finally, stupor, excitation, nudism, verbigeration, perseveration, staring, and vegetative instability have been interpreted as catatonic [3, 5, 15, 18, 42, 43]. In schizophrenia, the most frequent catatonic symptoms are mutism, posturing, stereotypies, and mannerisms [35, 67]. Due to these definition problems, the reported prevalence rates of catatonia in schizophrenia vary extensively (table 1). In a birth cohort study from Israel, $7.6 \%$ of the subjects who developed schizophrenia by the age of 35 years displayed the catatonic subtype [68]. The prevalence of catatonia appeared to decrease over the past century $[69,70]$. However, this effect is attributed to a decreased recognition of the syndrome rather than to a real decline in prevalence rates $[8,71]$. Indeed, moving away from categorical data, surprisingly high rates of schizophrenia patients endorse at least 1 sign in catatonia rating scales: $80 \%$ in chronically medicated patients [36] and $31 \%$ in first-episode, medication-naïve patients [67]. In first-episode patients, catatonic symptoms were responsive to antipsychotic treatment [57].

\section{Parkinsonism}

Parkinsonism has 6 main clinical features: resting tremor, rigidity, bradykinesia, loss of postural reflexes, flexed posture, and motor blocking (freezing) [72]. In schizophrenia, muscle rigidity and bradykinesia were the most frequently reported parkinsonian signs [10]. The Caligiuri group [73, 74] used a variety of instrumental measures to reappraise spontaneous parkinsonism in schizophrenia, a finding that has later been replicated using clinical rating scales $[13,34,35,75,76]$. Meta-analytic results demonstrated an odds ratio of 5.32 for spontaneous parkinsonism in never-treated schizophrenia subjects [58]. Parkinsonism of unmedicated first-episode patients was shown to deteriorate with antipsychotic treatment in some patients $(28 \%)$, while in others, parkinsonism was unchanged (15\%) or ameliorated $(6 \%)$ with treatment [57]. Spontaneous parkinsonism was suggested to predict neuroleptic-induced parkinsonism [73]. Druginduced parkinsonism has been shown in first- and second-generation antipsychotics at high incidence and prevalence rates $[23,37,77]$.

\section{Negative Syndrome}

Negative symptoms constitute one dimension of schizophrenia. They refer to the loss of affective experience and expression, as well as to a number of symptoms associated with disturbances of volition, such as apathy, avolition, and anhedonia. Negative symptoms may be as- sociated primarily with schizophrenia or may develop secondary to social deprivation, antipsychotic medication, or depression $[78,79]$. As a result, the patients are less active. The psychomotor poverty syndrome has been linked to negative symptoms, comprising decreased spontaneous movements and flattened affect [80]. Indeed, the objectively assessed amount of movement has been associated with negative symptoms [81-83].

\section{Psychomotor Slowing}

Morrens et al. [12] have reviewed the data on reduced processing speed (psychomotor slowing) that can be assessed with reaction time, fine motor, drawing and writing, or the symbol digit substitution task. They found a high prevalence of slowing, which was associated with negative symptoms, but independent from antipsychotic medication [12, 84, 85]. Furthermore, reduced physical activity in schizophrenia patients was reported in epidemiologic studies using self-reports $[86,87]$, as well as in instrumental assessments using gait analyses $[88,89]$ or wrist actigraphy [83, 90-93].

Consistently, considerable prevalence rates have been reported for motor symptoms in schizophrenia (table 1). For illustration purposes, we have chosen the low cutoff scores of most studies, i.e. 1 NSS symptom or 2 catatonia symptoms. However, prevalence rates vary between studies because of different instruments and cutoff scores.

Some motor symptoms in schizophrenia are persistent over time. This applies particularly to drug-induced movement disorders in chronic patients [102-104] but also to parkinsonism in medication-naïve patients [57, 99]. NSS deteriorate in chronic patients over time [104]. In contrast, NSS in first-episode patients were observed to improve during an episode, even more so in patients with an overall favorable outcome [105-107]. The course of catatonia is heterogeneous. Catatonic symptoms may resolve with treatment in some cases, however persistence or deterioration are also frequently observed $[8,34$, $42,67,108-112]$. Finally, intraindividual variations in symptom presentation and severity have been reported for all motor signs in schizophrenia.

\section{Neurobiology of the Motor System in Schizophrenia}

\section{Motor System Anatomy}

The human motor system in the brain includes the motor and premotor cortices, the basal ganglia, brainstem, the cerebellum, and the white matter tracts connecting these components [for review, see 72, 113]. We 
will briefly focus on the anatomy and function of motor cortices, basal ganglia, and corresponding fiber tracts associated with schizophrenia or motor dysfunction. The system is organized in different parallel loops. Cortical motor fields include the primary motor cortex (M1), the supplemental motor area (SMA), the dorsal and ventral premotor areas (PMd and $\mathrm{PMv}$, respectively), and the rostral and caudal cingulate motor areas (CMAr and CMAc, respectively). All of them are somatotopically organized and interconnected to M1. Each of the cortical areas projects to the basal ganglia and receives input from the motor thalamus [113]. The lateral premotor fields (PMd and $\mathrm{PMv}$ ) are involved in goal-directed movements, while the medial premotor fields (SMA, pre-SMA, CMAr, and CMAc) engage in motor planning and execution. Furthermore, the latter group has been implicated in volitional aspects of behavior and drive [114]. The basal ganglia involved in motor behavior comprise the striatum (including caudate and putamen), the globus pallidus (internal and external division), the subthalamic nucleus (STN), and the substantia nigra $[72,113]$. Two main loops are involved in motor control. The first is the excitatoryacting direct pathway, including 2 inhibitory $\gamma$-aminobutyric acid (GABA)ergic synapses from the striatum to the internal pallidum and thalamus; the putaminal neurons of the direct pathway contain dopamine $\mathrm{D}_{2}$ receptors. The second is the inhibitory indirect pathway, including 3 inhibitory GABAergic synapses from the striatum to the external pallidum, to the STN, to the internal pallidum, and the thalamus. The putaminal neurons of the indirect pathway have dopamine $\mathrm{D}_{1}$ receptors, and the synapses between STN and internal pallidum are glutamatergic. Both pathways start with glutamatergic inputs from (pre)motor cortices to the striatum and end with glutamatergic afferents from the thalamus to the motor cortices [115]. Under normal conditions, the output of both pathways is balanced, leading to an inhibitory tone on the thalamic nuclei, which is disinhibited whenever an action is performed $[72,116]$.

The motor loop receives cortical input via the neostriatum and the STN. The STN is a key input region, receiving direct glutamatergic afferents from the (pre)motor cortices and dopaminergic input from the substantia nigra [117]. Recent evidence also suggests that there are dopaminergic projections to the extrastriatal basal ganglia (globus pallidus, substantia nigra, and STN), where dopamine may facilitate motor activity [118].

This short description is simplified, as the human motor system is far more complex than the current models suggest. In addition, most models focus exclusively on dopamine, GABA, and glutamate, even though more neurotransmitters are involved.

\section{Neuropathology}

Neuropathological studies in schizophrenia have focused on the limbic system, the hippocampus, and the dorsolateral prefrontal cortex [for review, see 119, 120]. However, reports on the motor system are rare. The results on neuron density in the premotor, motor, and anterior cingulate cortices (ACC) are inconclusive [120]. However, reduced synaptic density and aberrant wiring were found in the ACC; interestingly, Fornito et al. [121] found brain volume reduction in Brodmann area 24, which contains the cingulate motor areas (CMAr and CMAc). The results for basal ganglia remain inconsistent [120]. However, a recent study indicated reduced neuron number and volume of the putamen and caudate in schizophrenia [122]. Furthermore, reduced thalamus volumes were found [for review, see ref. 120, 123]. It has been suggested that antipsychotic drugs have differential regional effects on basal ganglia structure [124]. An influential review on the involvement of the basal ganglia in schizophrenia pathology was written by Graybiel [125].

In general, disturbed GABAergic neurotransmission was found in several brain regions, including the anterior cingulate and primary motor cortex [126]. Furthermore, GABA synthesis is reduced in the caudate nucleus, anterior nucleus of the thalamus, and ACC [127]. The GABAergic tone within the basal ganglion system further suggests that some motor symptoms may be the result of GABAergic dysfunction in schizophrenia. Dysfunctional GABA transmission has been suggested as a putative cause of some catatonic symptoms such as stupor [128-130].

Glutamatergic dysfunction has been suggested in the pathogenesis of schizophrenia [131, 132]. Some studies have investigated this issue within the schizophrenia motor system and indicated altered glutamate neurotransmission in the caudate and putamen [133, 134]. Higher levels of glutamatergic neurotransmission were found in the cerebrospinal fluid of schizophrenia patients with TD [135]. Moreover, in akinetic catatonic schizophrenia, glutamate hyperfunction was suggested as $N$-methyl-D-aspartate (NMDA) antagonists were reported to alleviate acute hypokinetic catatonia $[128,136]$.

In summary, neuropathological alterations in the motor system in schizophrenia have been located in the ACC, putamen, caudate, and thalamus. In addition, GABAergic deficits also included M1. 


\section{Neuroimaging Findings}

Since the 1970s, an increasing number of papers on neuroimaging in schizophrenia have been published. Most studies have focused on prefrontal cortical abnormalities by investigating structure, perfusion, and function. Again, the proportion of studies specifically addressing motor symptoms has remained low. Structural neuroimaging studies reported increased volumes of the caudate, putamen, and globus pallidus in medicated schizophrenia patients [137]. However, in the putamen of unmedicated patients, volumes were reduced [138]. In contrast, thalamic volumes are reduced in schizophrenia [139-142]. In both chronic and first-episode schizophrenia meta-analyses, researchers reported widespread gray matter reductions in the thalamo-cortico-striatal circuit, including the medial dorsal nucleus of the thalamus, the ACC, and the caudate nucleus $[121,142,143]$. The findings on resting state cerebral blood flow $(\mathrm{CBF})$ and metabolism of the basal ganglia were inhomogeneous [for review, see ref. 144]. A meta-analysis of magnetic resonance spectroscopy findings demonstrated reduced glutamate and increased glutamine levels in the frontal cortex of schizophrenia patients [132]. Patient treatment with antipsychotic medications is a major limitation of the literature on the motor system in schizophrenia patients; these medications affect brain structure and neurotransmission [for review, see ref. 124].

Neuroimaging results for dyskinesia remain inconclusive, with reduced ventricle-to-brain ratios [145], reduced caudate volumes [146], increased volumes of the left lentiform nucleus (putamen and globus pallidus) [147], or no changes reported [148]. Glucose metabolic rates in the globus pallidus and primary motor cortex were found to be higher in patients with dyskinesia [149]. Likewise, neurological signs were linked to structural alterations. Indeed, motor deficits as a component of NSSs were found to be associated with gray matter loss in the motor cortices, caudate nucleus, and thalamus (see also online suppl. table 2) [150-155].

In catatonia, no structural abnormalities have emerged so far. However, single case reports noted reduced bilateral frontal CBF [156] or hypometabolism [157], along with bilateral thalamic hypermetabolism [157]. Similarly, the case series of Northoff et al. $[129,158]$ of a mixeddiagnosis catatonia group (3/10 with schizophrenia) revealed hypoperfusion in the middle and right lower prefrontal cortex. The finding was corroborated by functionalmagnetic resonanceimaging(fMRI) demonstrating hypoactivation of $\mathrm{M} 1$ during a sequential finger opposition task in akinetic patients $[159,160]$. In addition, fMRI revealed reduced activation of the SMA in simple motor tasks in catatonic or akinetic patients $[160,161]$. Furthermore, one study demonstrated reduced $\mathrm{GABA}_{\mathrm{A}}$ density in the left M1 of akinetic catatonia patients [129], emphasizing a GABAergic dysfunction in catatonia.

Parkinsonian symptoms assessed with scales or instrumental measures were found to correlate with striatal $\mathrm{D}_{2}$ receptor occupancy $[162,163]$. No study on parkinsonism in schizophrenia applied fMRI or elaborated structural imaging.

Persistent negative symptoms, as in deficit schizophrenia, were associated with reduced volumes of bilateral frontal and temporal lobes, left ACC, left SMA, and right putamen as compared to non-deficit patients [164, 165]. In a large factor analysis, negative symptoms were linked with widespread reductions in prefrontal gray matter and thalamic volume [166].

Motor slowing, as measured by actigraphy, has been associated with reduced left ACC volume [81], and reduced CBF in the CMAr and bilateral prefrontal cortex [91]; similarly, psychomotor retardation correlated with $\mathrm{CBF}$ in the left dorsolateral prefrontal cortex and inversely with CBF in bilateral caudate nuclei [167].

Alterations in the premotor areas were linked to motor skill learning in schizophrenia, e.g. reduced pre-SMA gray matter volume [168] or aberrant signal changes in ACC, and premotor and motor cortices in schizophrenia $[169,170]$. In addition, a variety of studies applied simple hand motor tasks, demonstrating reduced activation of SMA and M1 in schizophrenia $[161,171]$. For a complete list of related studies, please refer to the online supplementary table 3 . As methodological issues limit a majority of these studies, replication of the findings with current neuroimaging standards would be informative.

In summary, neuroimaging results of different modalities support the view of altered structure and function of the motor system in schizophrenia. Some of the specific symptoms are related to dysfunctions of the basal ganglia, and premotor and motor cortices. Disturbances in the initiation of movements, as studied with finger tapping in akinetic patients, have been associated with M1 or SMA hypofunction $[159,160]$, whereas disturbed voluntary action was associated with alterations if the SMA and ACC, including the CMA $[81,91,164,165]$.

\section{Animal Models}

Animal models of schizophrenia have the potential to test hypotheses of aberrant neurodevelopment and behavior to facilitate the understanding of neurobiology. However, current translational research methods target- 
ing schizophrenia suffer from several inherent problems such as poor validity of interspecies comparisons [172]. There are animal models of basal ganglia dysfunctions that resemble Parkinson and Huntington's disease. It remains unclear, however, how much can be learned about schizophrenia from these models. Since positive symptoms have been associated with spontaneous or amphetamine-induced hyperactivity in rodent models of schizophrenia, most of the studies involve motor tasks [173].

Animal models of dyskinesia investigated the effects of dopamine receptor occupancy [174, 175], GABAergic transmission [176], and prenatal lesions [177]. A correlate of NSS was seen in mice lacking the presynaptic protein complexin 2, which was attenuated by a second hit [178]. Fine motor impairments were reported in rats with partial lesions in the substantia nigra [179].

Catalepsy has been used to model akinesia in druginduced parkinsonism. The phenomenon occurs in rats at striatal $\mathrm{D}_{2}$ receptor occupancy above $85 \%$ [180], but dopamine may not account for all cataleptic effects [174]. In addition, the administration of a $\mathrm{D}_{1}$ antagonist in the STN led to catalepsy in rats, an effect not seen with a $\mathrm{D}_{2}$ antagonist [181]. Catalepsy was also elicited by glutamate antagonists [182, 183].

Negative symptoms have been elicited by treatment with chronic phencyclidine, an NMDA antagonist [184186]. Mutant mouse models of negative symptoms suggest an involvement of $\mathrm{D}_{2}$ overexpression in avolition, even though most studies focused on impaired social behavior [187].

Reduced locomotion was seen in rats treated with typical and atypical antipsychotic drugs [174]. Perinatal treatment with MK-801 (an NMDA antagonist) increased motor activity during adolescence, but decreased locomotion during adulthood [188]. Similarly, postnatal mild hypoxia led to reduced locomotion in rats [189]. Furthermore, reduced locomotion was found in mutant mouse models of impaired glutamate or dopamine neurotransmission: vesicular monoamine transporter 2 gene-deficient mice [190], D-amino acid oxidase-knockout mice [191], cannabinoid-2-receptor-knockout mice [192], and sandy mutant mice that lack dysbindin [193].

Strikingly, two models of disturbed myelination with altered oligodendrocyte function resulted in reduced locomotor activity. First, in mutant ErbB4-deficient mice, oligodendrocytes were structurally altered, myelin thickness was reduced, and dopamine receptors were increased [194]. Hemopexin knockout mice had a similar pattern, with reduced myelin basic protein in motor cortex and basal ganglia, altered myelin structure, reduced myelin thickness, and impaired oligodendrocyte maturation [195]. Therefore, reduced locomotor activity can result from both neurotransmitter changes and white matter alterations.

\section{White Matter}

The disconnectivity hypothesis of schizophrenia pathophysiology has gained much attention in the last 2 decades [196, 197]. It suggests an important role for the white matter in schizophrenia symptoms. Postmortem studies indicated abnormal gene expression in the cingulate gyrus, profoundly affecting myelination and oligodendrocyte function of schizophrenia patients [198]. Schizophrenia patients further demonstrate increased interstitial white matter neurons, indicating deficient migration from the white matter to the cortex [199]. In fact, maldistribution of neurons in the prefrontal white matter has been replicated [for review, see 200], including the anterior cingulate white matter [201]. ErbB4 signalling is thought to be involved in alterations of neural development, neurotransmission, and synaptic plasticity in schizophrenia [202].

Altered ErbB4 signalling was associated with NMDA receptor hypofunction in the prefrontal cortex in schizophrenia [203]. Altered white matter structure may also affect the motor system. In Brodmann area 6, which comprises pre-SMA and SMA, schizophrenia patients had reduced NRG1 (neuregulin 1) C-terminal fragments indicating altered NRG1 signalling in this premotor area [204]. This is especially important since the tangential migration of thalamocortical axons critically depends on the NRG1 gene and their ErbB4 receptor [205]. These findings of altered white matter-associated gene expression are congruent with several diffusion tensor imaging studies demonstrating aberrant white matter structure in the motor system of schizophrenia patients.

In both first-episode and chronic patients, alterations were found in motor tracts such as the internal capsule or the corpus callosum [142, 206-209], but also in the premotor and motor cortex [210]. Interestingly, in early-onset schizophrenia, white matter maturation is delayed, especially in bilateral frontal lobes and the pyramidal tract $[207,211]$.

Few studies have linked motor function to white matter structure in schizophrenia. In first-episode patients, impaired motor skills in a pegboard task were related to reduced fractional anisotropy in the anterior thalamic radiation and corticospinal tract [212]. Motor coordination was associated with white matter density in the left inferior frontal gyrus [150] and thalamus [154]. Further- 
more, actigraphically assessed motor activity in schizophrenia was linked to white matter integrity underneath the SMA [92]. We have recently found evidence for altered organization of motor pathways in schizophrenia, indicating that motor activity is linearly associated with the structural connectivity of the premotor cortex [213]. In a study on TD in schizophrenia patients, decreased white matter integrity was reported in the external capsule, cingulate, and around the putamen [206]. Despite these findings, the number of specific studies on white matter structures of the motor system in schizophrenia is still limited, and special populations such as elderly or chronic patients or unaffected siblings warrant investigation.

\section{Neurodevelopmental Aspects}

Humans have limited postnatal motor abilities. Neuromotor development is a process of learning and training closely linked to brain development. During the 1st year of life, the cerebellum grows extensively. During the 2nd year, the caudate increases gray matter relative to total brain volume [214].

Longitudinal in vivo MRI studies provided valuable insight into region-specific human brain maturation [215]. Gray matter maturation in motor cortices begins early in the primary motor cortex and spreads towards the premotor areas [216], resulting in an early cortical motor network that is further developed until late adolescence [217]. In contrast, white matter density in the bilateral posterior limbs of the internal capsule increases linearly between the ages of 4 and 17 years, indicating maturation in motor pathways such as the corticospinal tract $[218,219]$.

Schizophrenia has been conceptualized as a lifetime trajectory of neurodevelopmental changes, which, in combination with other causes, eventually lead to the typical course and psychopathology [220, 221]. In motor symptoms in schizophrenia, obstetric complications correlate with spontaneous movement disorders but not with drug-induced motor symptoms [51, 222]. In addition, maternal genital infection was associated with impaired fine motor abilities in adult schizophrenia patients [223].

Neuromotor development is one of the postnatal peculiarities of schizophrenia. Large birth cohort studies indicated delayed gross motor milestones (e.g. standing and walking), as well as impaired motor skills before the age of 11 years in a proportion of children who later developed schizophrenia [224-227]. A combination of delayed neuromotor development and obstetric complica- tions was shown to potentiate the risk of schizophrenia in adulthood [228]. Similarly, deficits in motor coordination at the age of 10 years were found to predict schizophrenia spectrum disorders 35 years later [229]. These findings were corroborated by structured analyses of childhood home videos that revealed increased neuromotor abnormalities and poorer motor skills in subjects who were later diagnosed with schizophrenia compared to their healthy siblings [230]. In fact, abnormal movements were predictive of conversion to psychosis in adolescents at risk (mean age, 14.5 years) [231].

Brain maturation is a dynamic process, and the timeframe of relevant changes is important for the disease process. According to twin theories of motor development and behavior, monozygotic twins discordant for schizophrenia diverged either before the age of 5 years (30\%) or between the age of 13 and 17 years (57\%) [232]. The age of divergence suggests a temporal effect of dysfunctional processes in motor-relevant brain areas. Consistently, in a birth-cohort study, the proportion of subjects with unusual movements during childhood dropped between the assessments at the age of 8 months, and 4 and 7 years for healthy controls $(13,5$, and $5 \%$, respectively) and unaffected siblings (17, 9, and $4 \%$, respectively), but not in schizophrenia patients $(19,15$, and $16 \%$, respectively) [227].

Motor developmental changes and abnormalities in childhood have been demonstrated to be predictors of adult schizophrenia. These alterations occur during the maturation of gray matter in the motor cortices [216] and the motor network [217]. During periadolescence, increased pruning of dendritic spines contributes to the gray matter loss in schizophrenia [233]. As schizophrenia is associated with delayed gray and white matter maturation in motor circuits [207], we may speculate that impaired childhood motor performance in schizophrenia is linked to brain maturation delays. One birth cohort study supports this notion: gray matter volume in the motor network and white matter density in the left internal capsule at the age of 33-35 years were associated with earlier infant motor development in healthy subjects, but not in schizophrenia patients [234].

The genetic findings on motor symptoms in schizophrenia remain inconclusive. Some findings point to an association of motor symptoms with the genetic risk of developing schizophrenia, since meta-analyses demonstrated that dyskinesia, NSS, and parkinsonism are more prevalent in unaffected first-degree relatives of patients with schizophrenia than in healthy controls $[58,235]$. 


\section{Summary of Motor System Abnormalities in}

Schizophrenia

There are several indications linking the neurobiology of the motor system with schizophrenia at the level of neuronal structure, function, and chemistry in the premotor and motor cortices, and the basal ganglia and thalamus, as well as in the connecting white matter pathways. Furthermore, there is converging evidence for a functional and chronological link between the development of the motor system and the trajectory of the disease, congruent with the neurodevelopmental hypothesis of schizophrenia [11, 220, 221].

\section{Conclusions and Outlook}

\section{Importance of the Motor Domain in Schizophrenia}

Motor symptoms were interpreted as an integral part of schizophrenia in the classic and preneuroleptic literature $[1,5,25]$. More recently, various motor symptoms have been reported in never-medicated first-episode patients and in patients at risk for psychosis $[10,13,34,62$, 236].

Motor symptoms in schizophrenia, however, are not restricted to catatonia or NSS. We have addressed a variety of symptoms, taking into account that further motor disorders have been described, including oculomotor dysfunction [237, 238] or impaired hand gestures [239]. Given that some motor symptoms are present in a majority of patients and that they can be found during the entire course of the disease, we conclude that they form an important domain of schizophrenia pathophysiology $[8$, 11]. However, the conflicting definitions of motor symptoms in schizophrenia reduce perception and research interest, and render the comparison of the related studies difficult. Furthermore, the debate on whether motor symptoms are an integral part of nosological schizophrenia or whether they are a loosely connected expression of a general neurodevelopmental disorder does not appear to be helpful for a comprehensive view of the manifold phenomena.

The motor domain includes a variety of motor abnormalities with varying degrees of severity. Since the diverse concepts suggest different objects of research and lead to incompatible study results, there is an urgent need for a common descriptive clinical foundation and neurobiological reference. On the basis of this review, we conclude that motor symptoms should be described in objective, concept-independent terms along dimensions such as quantity, sequencing, coordination, goal directedness, intrusion, omission, and negativism. Furthermore, research should be focused on referring these phenomena to the underlying brain systems and their development.

Triggered by articles on the specificity of catatonia [6$8]$ and on motor symptoms in drug-naïve patients $[11,58$, 236], researchers currently debate whether motor symptoms should receive more attention in the DSM-V for schizophrenia. While the majority of researchers may agree that movement disorders are intrinsic to schizophrenia pathobiology [11], serious doubts have been raised about whether movement disorders are specific to schizophrenia, given their prevalence in other endogenous psychoses $[60,62,236]$.

We have shown that several components of the motor system are affected by schizophrenia, including white matter and basal ganglia. Motor circuits mature during postnatal brain development [215] and in some instances, motor development is delayed in children who are later diagnosed with schizophrenia [224, 228]. Therefore, the development of motor circuits may be critical in schizophrenia. In particular, deficient migration and function of GABAergic interneurons, as well as impaired mRNA expression related to myelination, are thought to focally alter the brain in schizophrenia [198]. Similar local impairments in motor circuit components may represent the weak link in the chain of this important brain system, rendering it dysfunctional under stress.

The symptoms range from mild and basic disturbances such as hypokinetic and hyperkinetic movement disorders, i.e. parkinsonism and abnormal involuntary movements. In addition, higher motor functions such as coordination, planning, fine-tuning, and learning of motion sequences may be impaired. Finally, schizophrenia patients demonstrate disturbances in intention or will. The latter might originate from both cognitive and motor deficits, but it has also been connected with the function of the pre-SMA and ACC [114]. We suggest that disturbed volition and initiation of movements in schizophrenia may result from dysfunctions of the premotor cortices and of impaired structural connectivity. In addition, bradykinesia may be due to dysfunctional basal ganglion output on thalamocortical pathways.

Finally, the various motor symptoms in schizophrenia have been demonstrated to be important in treatment $[34,240]$ and rehabilitation $[87,240]$. Most importantly, motor symptoms may disturb communication, provoking false signals about one's intentions. The most severe disturbances in communication would be catatonic mutism, negativism, and stupor. However, less pronounced motor disturbances might also affect communication. In 
fact, parkinsonism in schizophrenia has been shown to alter speech [241], and negative symptoms have been associated with reduced abilities to imitate emotional face expressions and hand gestures [239]. It is further conceivable that symptoms such as dyskinesia or grimacing may disrupt facial emotion expression. Other motor aspects of nonverbal communication such as posture $[15,34,35]$ and gait $[34,35,88]$ are also altered in schizophrenia. Thus, communication disturbances in schizophrenia may not only relate to formal thought disorder [242, 243] and affective disturbances $[244,245]$ but also to motor symptoms.

\section{Assessment of Schizophrenia Motor Symptoms}

In recent decades, motor symptoms lost importance in psychiatric assessments. As a result, such symptoms have been increasingly ignored [71]. Renewed awareness of psychomotor symptoms in schizophrenia is necessary to develop comprehensive knowledge about the condition $[7,8,65]$. Operational, unitary, and objective instruments for the assessment of motor disorders are needed, since, compared to rating scales, sensitivity for detecting motor symptoms has been shown to be superior for objective measurements [74, 82].

We propose that single motor symptoms should be investigated descriptively, irrespective of historical con- cepts, and symptom descriptions should be independent from presumed etiologies. With this strategy, reduced motor activity (or bradykinesia) was quantified $[83,91]$ and related to abnormal local resting brain perfusion [91], reduced cingulate gray matter [81], and alterations in white matter integrity [92].

\section{Future Directions}

We identify three important areas of future research. First, elaborated neuroimaging studies and longitudinal designs are needed to further clarify the impairments in the schizophrenia motor circuitry at different stages of development and in unaffected siblings. Second, further animal models of motor dysfunction are required to elucidate the impact of delayed maturation, as well as the gene-environment interaction on motor function. Third, postmortem brain investigations should clarify the neurochemical and structural role of altered white matter structure as presented in neuroimaging studies. The conceptual work should be addressed to unify the findings on a common basis. We suggest that this basis is the functionality of the motor system. To the best of our current knowledge, these dysfunctions should not be limited by categorical boundaries but rather be described and studied as a dimension linked to neurodevelopmental disorders of schizophrenia.

\section{References}

1 Bleuler E: Dementia praecox oder Gruppe der Schizophrenien. Leipzig, Deuticke, 1911.

2 Kahlbaum K: Die Katatonie oder das Spannungsirresein. Eine klinische Form psychischer Krankheit. Berlin, Hirschwald, 1874.

3 Kleist K: Die Katatonien. Nervenarzt 1943; 16:1-10.

4 Leonhard K: Die Aufteilung der endogenen Psychosen und ihre differenzierte Ätiologie. Stuttgart, Thieme, 1995

5 Kraepelin E: Psychiatrie. Ein Lehrbuch für Studierende und Ärzte, ed 6. Leipzig, Barth, 1899.

6 Fink M, Shorter E, Taylor MA: Catatonia is not schizophrenia: Kraepelin's error and the need to recognize catatonia as an independent syndrome in medical nomenclature. Schizophr Bull 2010;36:314-320.

-7 Heckers S, Tandon R, Bustillo J: Catatonia in the DSM - shall we move or not? Schizophr Bull 2010;36:205-207.

-8 Ungvari GS, Caroff SN, Gerevich J: The catatonia conundrum: evidence of psychomotor phenomena as a symptom dimension in psychotic disorders. Schizophr Bull 2010;36: 231-238.
9 Bombin I, Arango C, Buchanan RW: Significance and meaning of neurological signs in schizophrenia: two decades later. Schizophr Bull 2005;31:962-977.

10 Pappa S, Dazzan P: Spontaneous movement disorders in antipsychotic-naive patients with first-episode psychoses: a systematic review. Psychol Med 2009;39:1065-1076.

11 Whitty PF, Owoeye O, Waddington JL: Neurological signs and involuntary movements in schizophrenia: intrinsic to and informative on systems pathobiology. Schizophr Bull 2009;35:415-424.

12 Morrens M, Hulstijn W, Sabbe B: Psychomotor slowing in schizophrenia. Schizophr Bull 2007;33:1038-1053.

13 Wolff AL, O’Driscoll GA: Motor deficits and schizophrenia: the evidence from neuroleptic-naive patients and populations at risk. J Psychiatry Neurosci 1999;24:304-314.

14 Torrey EF: Studies of individuals with schizophrenia never treated with antipsychotic medications: a review. Schizophr Res 2002;58:101-115.

15 Rogers D: The motor disorders of severe psychiatric illness: a conflict of paradigms. Br J Psychiatry 1985;147:221-232.
16 Turner T: Rich and mad in Victorian England. Psychol Med 1989;19:29-44.

17 Kraepelin E: Psychiatrie. Ein kurzes Lehrbuch für Studierende und Ärzte, ed 4. Leipzig, Abel, 1893.

18 Kraepelin E: Einführung in die psychiatrische Klinik. Leipzig, Barth, 1921.

19 Jaspers K: Allgemeine Psychopathologie. Ein Leitfaden für Studierende, Ärzte und Psychologen. Berlin, Springer, 1913.

20 Schneider K: Klinische Psychopathologie, ed 15. Stuttgart, Thieme, 2007.

21 Strik W, Dierks T: Biologische Psychopathologie, ed 1st. Stuttgart, Kohlhammer, 2011.

22 Manschreck TC, Maher BA, Rucklos ME, Vereen DR: Disturbed voluntary motor activity in schizophrenic disorder. Psychol Med 1982;12:73-84.

23 Ayd FJ Jr: A survey of drug-induced extrapyramidal reactions. JAMA 1961;175:10541060.

24 Crane GE, Naranjo ER: Motor disorders induced by neuroleptics: a proposed new classification. Arch Gen Psychiatry 1971;24:179184 . 
-25 Reiter PJ: Extrapyramidal motor-disturbances in dementia praecox. Acta Psychiatr Scand 1926;1:287-310.

-26 Mettler FA, Crandell A: Neurologic disorders in psychiatric institutions. J Nerv Ment Dis 1959;128:148-159.

27 Chapman J: The early symptoms of schizophrenia. Br J Psychiatry 1966;112:225-251.

$\checkmark 28$ Torrey EF: Neurological abnormalities in schizophrenic patients. Biol Psychiatry 1980; 15:381-388

29 Stevens JR: Disturbances of ocular movements and blinking in schizophrenia. J Neurol Neurosurg Psychiatry 1978;41:10241030.

- 30 Heinrichs DW, Buchanan RW: Significance and meaning of neurological signs in schizophrenia. Am J Psychiatry 1988;145:11-18.

-31 Cunningham Owens DG, Johnstone EC: The disabilities of chronic schizophrenia - their nature and the factors contributing to their development. Br J Psychiatry 1980;136:384395.

- 32 Fenton WS, Wyatt RJ, McGlashan TH: Risk factors for spontaneous dyskinesia in schizophrenia. Arch Gen Psychiatry 1994;51:643650

33 Owens DG, Johnstone EC, Frith CD: Spontaneous involuntary disorders of movement: their prevalence, severity, and distribution in chronic schizophrenics with and without treatment with neuroleptics. Arch Gen Psychiatry 1982;39:452-461.

- 34 Peralta V, Campos MS, De Jalon EG, Cuesta MJ: Motor behavior abnormalities in drugnaive patients with schizophrenia spectrum disorders. Mov Disord 2010;25:1068-1076.

35 Peralta V, Cuesta MJ: Motor features in psychotic disorders. I. Factor structure and clinical correlates. Schizophr Res 2001;47:107116.

-36 Ungvari GS, Goggins W, Leung SK, Gerevich J: Schizophrenia with prominent catatonic features ('catatonic schizophrenia'). II. Factor analysis of the catatonic syndrome. Prog Neuropsychopharmacol Biol Psychiatry 2007;31:462-468.

- 37 Janno S, Holi M, Tuisku K, Wahlbeck K: Prevalence of neuroleptic-induced movement disorders in chronic schizophrenia inpatients. Am J Psychiatry 2004;161:160-163.

- 38 Ismail B, Cantor-Graae E, McNeil TF: Neurodevelopmental origins of tardivelike dyskinesia in schizophrenia patients and their siblings. Schizophr Bull 2001;27:629-641.

- 39 Peralta V, Cuesta MJ: Neuromotor abnormalities in neuroleptic-naive psychotic patients: antecedents, clinical correlates, and prediction of treatment response. Compr Psychiatry 2011;52:139-145.

- 40 Peralta V, Cuesta MJ: Negative parkinsonian, depressive and catatonic symptoms in schizophrenia: a conflict of paradigms revisited. Schizophr Res 1999;40:245-253.

-41 Fink M, Taylor MA: The catatonia syndrome: forgotten but not gone. Arch Gen Psychiatry 2009;66:1173-1177.
42 Rosebush PI, Hildebrand AM, Furlong BG, Mazurek MF: Catatonic syndrome in a general psychiatric inpatient population: frequency, clinical presentation, and response to lorazepam. J Clin Psychiatry 1990;51:357362.

43 Bush G, Fink M, Petrides G, Dowling F, Francis A: Catatonia. I. Rating scale and standardized examination. Acta Psychiatr Scand 1996;93:129-136.

44 Bush G, Petrides G, Francis A: Catatonia and other motor syndromes in a chronically hospitalized psychiatric population. Schizophr Res 1997;27:83-92.

45 Marsden CD, Jenner P: The pathophysiology of extrapyramidal side-effects of neuroleptic drugs. Psychol Med 1980;10:55-72.

46 van Harten PN, Hoek HW, Matroos GE, Koeter M, Kahn RS: The inter-relationships of tardive dyskinesia, parkinsonism, akathisia and tardive dystonia: the Curacao Extrapyramidal Syndromes Study II. Schizophr Res 1997;26:235-242.

47 McKenna PJ, Mortimer AM, Lund CE: The motor disorders of severe psychiatric illness: a conflict of paradigms. Br J Psychiatry 1988; 152:863-864.

48 McKenna PJ, Lund CE, Mortimer AM, Biggins CA: Motor, volitional and behavioural disorders in schizophrenia. 2. The 'conflict of paradigms' hypothesis. Br J Psychiatry 1991;158:328-336.

49 Ungvari GS, Leung SK, Ng FS, Cheung HK Leung T: Schizophrenia with prominent catatonic features ('catatonic schizophrenia'). I. Demographic and clinical correlates in the chronic phase. Prog Neuropsychopharmacol Biol Psychiatry 2005;29:27-38.

50 Docx L, Morrens M, Bervoets C, Hulstijn W, Fransen E, De Hert M, Baeken C, Audenaert $\mathrm{K}$, Sabbe B: Parsing the components of the psychomotor syndrome in schizophrenia. Acta Psychiatr Scand, E-pub ahead of print.

51 Peralta V, de Jalon EG, Campos MS, Basterra V, Sanchez-Torres A, Cuesta MJ: Risk factors, pre-morbid functioning and episode correlates of neurological soft signs in drug-naive patients with schizophrenia-spectrum disorders. Psychol Med 2011;41:1279-1289.

52 King DJ, Wilson A, Cooper SJ, Waddington JL: The clinical correlates of neurological soft signs in chronic schizophrenia. Br J Psychiatry 1991;158:770-775.

53 Morrens M, Hulstijn W, Lewi P, Sabbe B Bleuler revisited: Psychomotor slowing in schizophrenia as part of a catatonic symptom cluster. Psychiatry Res 2008;161:121125.

54 Waddington JL: Schizophrenia, affective psychoses, and other disorders treated with neuroleptic drugs: the enigma of tardive dyskinesia, its neurobiological determinants, and the conflict of paradigms. Int Rev Neurobiol 1989;31:297-353.

55 Khot V, Wyatt RJ: Not all that moves is tardive dyskinesia. Am J Psychiatry 1991;148: 661-666.
56 Quinn J, Meagher D, Murphy P, Kinsella A, Mullaney J, Waddington JL: Vulnerability to involuntary movements over a lifetime trajectory of schizophrenia approaches $100 \%$, in association with executive (frontal) dysfunction. Schizophr Res 2001;49:79-87.

57 Peralta V, Cuesta MJ: The effect of antipsychotic medication on neuromotor abnormalities in neuroleptic-naive nonaffective psychotic patients: a naturalistic study with haloperidol, risperidone, or olanzapine. Prim Care Companion J Clin Psychiatry 2010;12: PCC.09m00799.

-58 Koning JP, Tenback DE, van Os J, Aleman A, Kahn RS, van Harten PN: Dyskinesia and parkinsonism in antipsychotic-naive patients with schizophrenia, first-degree relatives and healthy controls: a meta-analysis. Schizophr Bull 2010;36:723-731.

59 Lee J, Poon LY, Chong SA: Spontaneous dyskinesia in first-episode psychosis in a Southeast Asian population. J Clin Psychopharmacol 2008;28:536-539.

60 Chong SA, Subramaniam M, Verma S: Spontaneous parkinsonism in antipsychotic-naive patients with first-episode psychosis. Can J Psychiatry 2005;50:429-431.

61 Koning JP, Tenback DE, Kahn RS, Vollema MG, Cahn W, van Harten PN: Movement disorders are associated with schizotypy in unaffected siblings of patients with non-affective psychosis. Psychol Med 2011;41:2141-2147.

62 Mittal VA, Neumann C, Saczawa M, Walker EF: Longitudinal progression of movement abnormalities in relation to psychotic symptoms in adolescents at high risk of schizophrenia. Arch Gen Psychiatry 2008;65:165171.

63 Mittal VA, Walker EF, Bearden CE, Walder D, Trottman H, Daley M, Simone A, Cannon TD: Markers of basal ganglia dysfunction and conversion to psychosis: neurocognitive deficits and dyskinesias in the prodromal period. Biol Psychiatry 2010;68:93-99.

64 Barkus E, Stirling J, Hopkins R, Lewis S: The presence of neurological soft signs along the psychosis proneness continuum. Schizophr Bull 2006:32:573-577.

65 Taylor MA, Fink M: Catatonia in psychiatric classification: a home of its own. Am J Psychiatry $2003 ; 160: 1233-1241$.

66 Northoff G, Wenke J, Krill W, Pflug B: Ball experiments in 32 acute akinetic catatonic patients: deficits of internal initiation and generation of movements. Mov Disord 1995; 10:589-595.

-67 Peralta V, Campos MS, de Jalon EG, Cuesta MJ: DSM-IV catatonia signs and criteria in first-episode, drug-naive, psychotic patients: psychometric validity and response to antipsychotic medication. Schizophr Res 2010; 118:168-175.

-68 Kleinhaus K, Harlap S, Perrin MC, Manor O, Weiser M, Harkavy-Friedman JM, Lichtenberg P, Malaspina D: Catatonic schizophrenia: a cohort prospective study. Schizophr Bull 2012;38:331-337. 
69 Morrison JR: Changes in subtype diagnosis of schizophrenia: 1920-1966. Am J Psychiatry 1974;131:674-677.

-70 Stompe T, Ortwein-Swoboda G, Ritter K, Schanda H, Friedmann A: Are we witnessing the disappearance of catatonic schizophrenia? Compr Psychiatry 2002;43:167-174.

-71 van der Heijden FM, Tuinier S, Arts NJ, Hoogendoorn ML, Kahn RS, Verhoeven WM: Catatonia: disappeared or under-diagnosed? Psychopathology 2005;38:3-8.

72 Fahn S, Jankovic J: Principles and Practice of Movement Disorders, ed 1. Philadelphia, Churchill Livingstone Elsevier, 2007.

-73 Caligiuri MP, Lohr JB: Instrumental motor predictors of neuroleptic-induced parkinsonism in newly medicated schizophrenia patients. J Neuropsychiatry Clin Neurosci 1997;9:562-567.

74 Caligiuri MP, Lohr JB, Jeste DV: Parkinsonism in neuroleptic-naive schizophrenic patients. Am J Psychiatry 1993;150:1343-1348.

75 Honer WG, Kopala LC, Rabinowitz J: Extrapyramidal symptoms and signs in first-episode, antipsychotic exposed and non-exposed patients with schizophrenia or related psychotic illness. J Psychopharmacol 2005; 19:277-285.

-76 McCreadie RG, Srinivasan TN, Padmavati $\mathrm{R}$, Thara R: Extrapyramidal symptoms in unmedicated schizophrenia. J Psychiatr Res 2005;39:261-266.

-77 Leucht S, Corves C, Arbter D, Engel RR, Li C, Davis JM: Second-generation versus firstgeneration antipsychotic drugs for schizophrenia: a meta-analysis. Lancet 2009;373: 31-41.

-78 Tandon R, Nasrallah HA, Keshavan MS: Schizophrenia, 'just the facts' 4 . Clinical features and conceptualization. Schizophr Res 2009;110:1-23

-79 Buchanan RW: Persistent negative symptoms in schizophrenia: an overview. Schizophr Bull 2007;33:1013-1022.

80 Liddle PF: The symptoms of chronic schizophrenia. A re-examination of the positivenegative dichotomy. Br J Psychiatry 1987; 151:145-151.

\$1 Farrow TF, Hunter MD, Wilkinson ID, Green RD, Spence SA: Structural brain correlates of unconstrained motor activity in people with schizophrenia. Br J Psychiatry 2005; 187:481-482.

82 Walther S, Koschorke P, Horn H, Strik W: Objectively measured motor activity in schizophrenia challenges the validity of expert ratings. Psychiatry Res 2009;169:187190.

83 Wichniak A, Skowerska A, Chojnacka-Wojtowicz J, Taflinski T, Wierzbicka A, Jernajczyk W, Jarema M: Actigraphic monitoring of activity and rest in schizophrenic patients treated with olanzapine or risperidone. J Psychiatr Res 2011;45:1381-1386.
84 Morrens M, Hulstijn W, Matton C, Madani Y, van Bouwel L, Peuskens J, Sabbe BG: Delineating psychomotor slowing from reduced processing speed in schizophrenia. Cogn Neuropsychiatry 2008;13:457-471.

85 Morrens M, Hulstijn W, Van Hecke J, Peuskens J, Sabbe BG: Sensorimotor and cognitive slowing in schizophrenia as measured by the symbol digit substitution test. J Psychiatr Res 2006;40:200-206.

-86 Brown S, Birtwistle J, Roe L, Thompson C: The unhealthy lifestyle of people with schizophrenia. Psychol Med 1999;29:697-701.

87 McLeod HJ, Jaques S, Deane FP: Base rates of physical activity in Australians with schizophrenia. Psychiatr Rehabil J 2009;32:269275.

88 Putzhammer A, Heindl B, Broll K, Pfeiff L, Perfahl M, Hajak G: Spatial and temporal parameters of gait disturbances in schizophrenic patients. Schizophr Res 2004;69: 159-166.

89 Putzhammer A, Perfahl M, Pfeiff L, Hajak G: Correlation of subjective well-being in schizophrenic patients with gait parameters, expert-rated motor disturbances, and psychopathological status. Pharmacopsychiatry 2005;38:132-138.

90 Berle JO, Hauge ER, Oedegaard KJ, Holsten F, Fasmer OB: Actigraphic registration of motor activity reveals a more structured behavioural pattern in schizophrenia than in major depression. BMC Res Notes 2010;3: 149.

91 Walther S, Federspiel A, Horn H, Razavi N, Wiest R, Dierks T, Strik W, Muller TJ: Resting state cerebral blood flow and objective motor activity reveal basal ganglia dysfunction in schizophrenia. Psychiatry Res 2011; 192:117-124

$\checkmark 92$ Walther S, Federspiel A, Horn H, Razavi N, Wiest R, Dierks T, Strik W, Muller TJ: Alterations of white matter integrity related to motor activity in schizophrenia. Neurobiol Dis 2011;42:276-283.

93 Walther S, Horn H, Razavi N, Koschorke P, Wopfner A, Muller TJ, Strik W: Higher motor activity in schizophrenia patients treated with olanzapine versus risperidone. J Clin Psychopharmacol 2010;30:181-184.

94 Browne S, Clarke M, Gervin M, Lane A, Waddington JL, Larkin C, O'Callaghan E: Determinants of neurological dysfunction in first episode schizophrenia. Psychol Med 2000;30:1433-1441.

95 Dazzan P, Lloyd T, Morgan KD, Zanelli J, Morgan C, Orr K, Hutchinson G, Fearon P, Allin M, Rifkin L, McGuire PK, Doody GA, Holloway J, Leff J, Harrison G, Jones PB, Murray RM: Neurological abnormalities and cognitive ability in first-episode psychosis. Br J Psychiatry 2008;193:197-202.

-96 Zabala A, Robles O, Parellada M, Moreno DM, Ruiz-Sancho A, Burdalo M, Medina O, Arango C: Neurological soft signs in adolescents with first episode psychosis. Eur Psychiatry 2006;21:283-287.
-97 Gupta S, Andreasen NC, Arndt S, Flaum M, Schultz SK, Hubbard WC, Smith M: Neurological soft signs in neuroleptic-naive and neuroleptic-treated schizophrenic patients and in normal comparison subjects. Am J Psychiatry 1995;152:191-196.

-98 Ismail B, Cantor-Graae E, McNeil TF: Neurological abnormalities in schizophrenic patients and their siblings. Am J Psychiatry 1998; 155:84-89.

-99 Cortese L, Caligiuri MP, Malla AK, Manchanda R, Takhar J, Haricharan R: Relationship of neuromotor disturbances to psychosis symptoms in first-episode neuroleptic-naive schizophrenia patients. Schizophr Res 2005;75:65-75.

-100 Tsai HT, Caroff SN, Miller del D, McEvoy J, Lieberman JA, North KE, Stroup TS, Sullivan PF: A candidate gene study of tardive dyskinesia in the CATIE schizophrenia trial. Am J Med Genet B Neuropsychiatr Genet 2010;153B:336-340.

101 Chakos MH, Mayerhoff DI, Loebel AD, Alvir JM, Lieberman JA: Incidence and correlates of acute extrapyramidal symptoms in first episode of schizophrenia. Psychopharmacol Bull 1992;28:81-86.

102 Bakker PR, de Groot IW, van Os J, van Harten PN: Long-stay psychiatric patients: a prospective study revealing persistent antipsychotic-induced movement disorder. PLoS One 2011;6:e25588.

103 Tenback DE, van Harten PN, Slooff CJ, van Os J: Incidence and persistence of tardive dyskinesia and extrapyramidal symptoms in schizophrenia. J Psychopharmacol 2010; 24:1031-1035.

104 Chen EY, Kwok CL, Au JW, Chen RY, Lau BS: Progressive deterioration of soft neurological signs in chronic schizophrenic patients. Acta Psychiatr Scand 2000;102:342349.

105 Schroder J, Niethammer R, Geider FJ, Reitz C, Binkert M, Jauss M, Sauer H: Neurological soft signs in schizophrenia. Schizophr Res 1991;6:25-30.

106 Bachmann S, Bottmer C, Schroder J: Neurological soft signs in first-episode schizophrenia: a follow-up study. Am J Psychiatry 2005;162:2337-2343.

107 Whitty P, Clarke M, Browne S, McTigue O, Kamali M, Feeney L, Lane A, Kinsella A, Waddington JL, Larkin C, O'Callaghan E: Prospective evaluation of neurological soft signs in first-episode schizophrenia in relation to psychopathology: state versus trait phenomena. Psychol Med 2003;33:14791484.

108 Kraepelin E: Über Remissionen bei Katatonie. Allg Z Psychiatr 1896;52:1126-1127.

109 Ungvari GS, Chiu HF, Chow LY, Lau BS, Tang WK: Lorazepam for chronic catatonia: a randomized, double-blind, placebocontrolled cross-over study. Psychopharmacology (Berl) 1999;142:393-398. 
110 Abrams R, Taylor MA: Catatonia. A prospective clinical study. Arch Gen Psychiatry 1976;33:579-581.

-111 Carroll BT: Kahlbaum's catatonia revisited. Psychiatry Clin Neurosci 2001;55:431-436.

- 112 Bush G, Fink M, Petrides G, Dowling F, Francis A: Catatonia. II. Treatment with lorazepam and electroconvulsive therapy. Acta Psychiatr Scand 1996;93:137-143.

113 Gombart L, Soares J, Alexander GE: Functional anatomy of basal ganglia and motor systems; in Watts RL, Koller WC (eds): Movement Disorders: Neurologic Principles and Practice. New York, McGraw-Hill, 2004, pp 87-100.

114 Haggard P: Human volition: towards a neuroscience of will. Nat Rev Neurosci 2008;9: 934-946.

115 Graybiel AM: The basal ganglia. Curr Biol 2000;10:R509-R511.

- 116 DeLong MR, Wichmann T: Circuits and circuit disorders of the basal ganglia. Arch Neurol 2007;64:20-24.

- 117 Hamani C, Saint-Cyr JA, Fraser J, Kaplitt M, Lozano AM: The subthalamic nucleus in the context of movement disorders. Brain 2004;127:4-20.

-118 Rommelfanger KS, Wichmann T: Extrastriatal dopaminergic circuits of the basal ganglia. Front Neuroanat 2010;4:139.

119 Dorph-Petersen KA, Lewis DA: Stereological approaches to identifying neuropathology in psychosis. Biol Psychiatry 2011;69: 113-126.

120 Harrison PJ: The neuropathology of schizophrenia. A critical review of the data and their interpretation. Brain 1999;122:593624.

- 121 Fornito A, Yucel M, Dean B, Wood SJ, Pantelis C: Anatomical abnormalities of the anterior cingulate cortex in schizophrenia: bridging the gap between neuroimaging and neuropathology. Schizophr Bull 2009; 35:973-993.

-122 Kreczmanski P, Heinsen H, Mantua V, Woltersdorf F, Masson T, Ulfig N, SchmidtKastner R, Korr H, Steinbusch HW, Hof PR, Schmitz C: Volume, neuron density and total neuron number in five subcortical regions in schizophrenia. Brain 2007;130: 678-692.

- 123 Byne W, Hazlett EA, Buchsbaum MS, Kemether E: The thalamus and schizophrenia: current status of research. Acta Neuropathol 2009;117:347-368.

- 124 Navari S, Dazzan P: Do antipsychotic drugs affect brain structure? A systematic and critical review of MRI findings. Psychol Med 2009;39:1763-1777.

125 Graybiel AM: The basal ganglia and cognitive pattern generators. Schizophr Bull 1997;23:459-469.
126 Hashimoto T, Bazmi HH, Mirnics K, Wu Q, Sampson AR, Lewis DA: Conserved regional patterns of GABA-related transcript expression in the neocortex of subjects with schizophrenia. Am J Psychiatry 2008; 165: 479-489.

127 Thompson M, Weickert CS, Wyatt E, Webster MJ: Decreased glutamic acid decarboxylase(67) mRNA expression in multiple brain areas of patients with schizophrenia and mood disorders. J Psychiatr Res 2009; 43:970-977.

128 Northoff G: Catatonia and neuroleptic malignant syndrome: psychopathology and pathophysiology. J Neural Transm 2002; 109:1453-1467.

129 Northoff G, Steinke R, Czcervenka C, Krause R, Ulrich S, Danos P, Kropf D, Otto $\mathrm{H}$, Bogerts B: Decreased density of GABAA receptors in the left sensorimotor cortex in akinetic catatonia: investigation of in vivo benzodiazepine receptor binding. J Neurol Neurosurg Psychiatry 1999;67:445450.

130 Ungvari GS, Leung CM, Wong MK, Lau J: Benzodiazepines in the treatment of catatonic syndrome. Acta Psychiatr Scand 1994;89:285-288.

131 Olney JW, Newcomer JW, Farber NB: NMDA receptor hypofunction model of schizophrenia. J Psychiatr Res 1999;33: 523-533.

132 Marsman A, van den Heuvel MP, Klomp DW, Kahn RS, Luijten PR, Hulshoff Pol HE: Glutamate in schizophrenia: a focused review and meta-analysis of $1 \mathrm{H}-\mathrm{MRS}$ studies. Schizophr Bull, E-pub ahead of print.

133 McCullumsmith RE, Meador-Woodruff JH: Striatal excitatory amino acid transporter transcript expression in schizophrenia, bipolar disorder, and major depressive disorder. Neuropsychopharmacology 2002;26:368-375.

134 Kristiansen LV, Meador-Woodruff JH: Abnormal striatal expression of transcripts encoding NMDA interacting PSD proteins in schizophrenia, bipolar disorder and major depression. Schizophr Res 2005;78:8793.

135 Tsai G, Goff DC, Chang RW, Flood J, Baer L, Coyle JT: Markers of glutamatergic neurotransmission and oxidative stress associated with tardive dyskinesia. Am J Psychiatry 1998;155:1207-1213.

136 Northoff G, Eckert J, Fritze J: Glutamatergic dysfunction in catatonia? Successful treatment of three acute akinetic catatonic patients with the NMDA antagonist amantadine. J Neurol Neurosurg Psychiatry 1997;62:404-406.

-137 Mamah D, Wang L, Barch D, de Erausquin GA, Gado M, Csernansky JG: Structural analysis of the basal ganglia in schizophrenia. Schizophr Res 2007;89:59-71.
138 Ballmaier M, Schlagenhauf F, Toga AW, Gallinat J, Koslowski M, Zoli M, Hojatkashani C, Narr KL, Heinz A: Regional patterns and clinical correlates of basal ganglia morphology in non-medicated schizophrenia. Schizophr Res 2008;106:140-147.

139 Gilbert AR, Rosenberg DR, Harenski K, Spencer S, Sweeney JA, Keshavan MS: Thalamic volumes in patients with first-episode schizophrenia. Am J Psychiatry 2001; 158:618-624.

140 Coscia DM, Narr KL, Robinson DG, Hamilton LS, Sevy S, Burdick KE, GunduzBruce H, McCormack J, Bilder RM, Szeszko PR: Volumetric and shape analysis of the thalamus in first-episode schizophrenia. Hum Brain Mapp 2009;30:1236-1245.

141 Lang DJ, Khorram B, Goghari VM, Kopala LC, Vandorpe RA, Rui Q, Smith GN, Honer WG: Reduced anterior internal capsule and thalamic volumes in first-episode psychosis. Schizophr Res 2006;87:89-99.

142 Bora E, Fornito A, Radua J, Walterfang M, Seal M, Wood SJ, Yucel M, Velakoulis D, Pantelis C: Neuroanatomical abnormalities in schizophrenia: a multimodal voxelwise meta-analysis and meta-regression analysis. Schizophr Res 2011;127:46-57.

143 Ellison-Wright I, Glahn DC, Laird AR, Thelen SM, Bullmore E: The anatomy of first-episode and chronic schizophrenia: an anatomical likelihood estimation metaanalysis. Am J Psychiatry 2008;165:10151023.

144 Buchsbaum MS, Hazlett EA: Positron emission tomography studies of abnormal glucose metabolism in schizophrenia. Schizophr Bull 1998;24:343-364.

145 Gold JM, Egan MF, Kirch DG, Goldberg TE, Daniel DG, Bigelow LB, Wyatt RJ: Tardive dyskinesia: neuropsychological, computerized tomographic, and psychiatric symptom findings. Biol Psychiatry 1991;30: 587-599.

146 Mion CC, Andreasen NC, Arndt S, Swayze VW 2nd, Cohen GA: MRI abnormalities in tardive dyskinesia. Psychiatry Res 1991;40: 157-166.

147 McCreadie RG, Thara R, Padmavati R, Srinivasan TN, Jaipurkar SD: Structural brain differences between never-treated patients with schizophrenia, with and without dyskinesia, and normal control subjects: a magnetic resonance imaging study. Arch Gen Psychiatry 2002;59:332336.

148 Waddington JL, O'Callaghan E, Buckley P, Madigan C, Redmond O, Stack JP, Kinsella A, Larkin C, Ennis JT: Tardive dyskinesia in schizophrenia. Relationship to minor physical anomalies, frontal lobe dysfunction and cerebral structure on magnetic resonance imaging. Br J Psychiatry 1995; 167: 41-44. 
149 Pahl JJ, Mazziotta JC, Bartzokis G, Cummings J, Altschuler L, Mintz J, Marder SR, Phelps ME: Positron-emission tomography in tardive dyskinesia. J Neuropsychiatry Clin Neurosci 1995;7:457-465.

-150 Thomann PA, Wustenberg T, Santos VD, Bachmann S, Essig M, Schroder J: Neurological soft signs and brain morphology in first-episode schizophrenia. Psychol Med 2009;39:371-379.

- 151 Venkatasubramanian G, Jayakumar PN, Gangadhar BN, Keshavan MS: Neuroanatomical correlates of neurological soft signs in antipsychotic-naive schizophrenia. Psychiatry Res 2008;164:215-222.

- 152 Dazzan P, Morgan KD, Orr KG, Hutchinson G, Chitnis X, Suckling J, Fearon P, Salvo J, McGuire PK, Mallett RM, Jones PB, Leff J, Murray RM: The structural brain correlates of neurological soft signs in AESOP first-episode psychoses study. Brain 2004; 127:143-153.

153 Keshavan MS, Sanders RD, Sweeney JA, Diwadkar VA, Goldstein G, Pettegrew JW, Schooler NR: Diagnostic specificity and neuroanatomical validity of neurological abnormalities in first-episode psychoses. Am J Psychiatry 2003;160:1298-1304.

154 Mouchet-Mages S, Rodrigo S, Cachia A, Mouaffak F, Olie JP, Meder JF, Oppenheim C, Krebs MO: Correlations of cerebellothalamo-prefrontal structure and neurological soft signs in patients with first-episode psychosis. Acta Psychiatr Scand 2011; 123:451-458.

- 155 Hirjak D, Wolf RC, Stieltjes B, Seidl U, Schroder J, Thomann PA: Neurological soft signs and subcortical brain morphology in recent onset schizophrenia. J Psychiatr Res 2012;46:533-539.

156 Galynker II, Weiss J, Ongseng F, Finestone $\mathrm{H}$ : ECT treatment and cerebral perfusion in catatonia. J Nucl Med 1997;38:251-254.

- 157 Lauer M, Schirrmeister H, Gerhard A, Ellitok E, Beckmann H, Reske SN, Stober G: Disturbed neural circuits in a subtype of chronic catatonic schizophrenia demonstrated by F-18-FDG-PET and F-18-DOPA-PET. J Neural Transm 2001;108:661670.

158 Northoff G, Steinke R, Nagel DC, Grosser O, Danos P, Genz A, Krause R, Boker H, Otto HJ, Bogerts B: Right lower prefrontoparietal cortical dysfunction in akinetic catatonia: a combined study of neuropsychology and regional cerebral blood flow. Psychol Med 2000;30:583-596.

-159 Northoff G, Braus DF, Sartorius A, Khoram-Sefat D, Russ M, Eckert J, Herrig M, Leschinger A, Bogerts B, Henn FA: Reduced activation and altered laterality in two neuroleptic-naive catatonic patients during a motor task in functional MRI. Psychol Med 1999;29:997-1002.
160 Payoux P, Boulanouar K, Sarramon C, Fabre N, Descombes S, Galitsky M, Thalamas C, Brefel-Courbon C, Sabatini U, Manelfe C, Chollet F, Schmitt L, Rascol O: Cortical motor activation in akinetic schizophrenic patients: a pilot functional MRI study. Mov Disord 2004;19:83-90.

161 Scheuerecker J, Ongseng F, Finestone H, Seifert D, Koutsouleris N, Moller HJ, Meisenzahl EM: Cerebral network deficits in post-acute catatonic schizophrenic patients measured by fMRI. J Psychiatr Res 2009;43: 607-614.

162 Tauscher J, Kufferle B, Asenbaum S, Fischer P, Pezawas L, Barnas C, Tauscher-Wisniewski S, Brucke T, Kasper S: In vivo ${ }^{123} \mathrm{I}$ IBZM SPECT imaging of striatal dopamine-2 receptor occupancy in schizophrenic patients treated with olanzapine in comparison to clozapine and haloperidol. Psychopharmacology (Berl) 1999;141:175181.

163 Heinz A, Knable MB, Coppola R, Gorey JG, Jones DW, Lee KS, Weinberger DR: Psychomotor slowing, negative symptoms and dopamine receptor availability - an IBZM SPECT study in neuroleptic-treated and drug-free schizophrenic patients. Schizophr Res 1998;31:19-26.

164 Galderisi S, Quarantelli M, Volpe U, Mucci A, Cassano GB, Invernizzi G, Rossi A, Vita A, Pini S, Cassano P, Daneluzzo E, De Peri L, Stratta P, Brunetti A, Maj M: Patterns of structural MRI abnormalities in deficit and nondeficit schizophrenia. Schizophr Bull 2008;34:393-401.

165 Cascella NG, Fieldstone SC, Rao VA, Pearlson GD, Sawa A, Schretlen DJ: Gray-matter abnormalities in deficit schizophrenia. Schizophr Res 2010;120:63-70.

166 Nenadic I, Sauer H, Gaser C: Distinct pattern of brain structural deficits in subsyndromes of schizophrenia delineated by psychopathology. Neuroimage 2010;49:11531160.

167 Liddle PF, Friston KJ, Frith CD, Hirsch SR, Jones T, Frackowiak RS: Patterns of cerebral blood flow in schizophrenia. Br J Psychiatry 1992;160:179-186.

168 Exner C, Weniger G, Schmidt-Samoa C, Irle E: Reduced size of the pre-supplementary motor cortex and impaired motor sequence learning in first-episode schizophrenia. Schizophr Res 2006;84:386-396.

169 Kodama S, Fukuzako H, Fukuzako T, Kiura T, Nozoe S, Hashiguchi T, Yamada K, Takenouchi K, Takigawa M, Nakabeppu Y, Nakajo M: Aberrant brain activation following motor skill learning in schizophrenic patients as shown by functional magnetic resonance imaging. Psychol Med 2001;31:1079-1088.
170 Rowland LM, Shadmehr R, Kravitz D, Holcomb HH: Sequential neural changes during motor learning in schizophrenia. Psychiatry Res 2008;163:1-12.

171 Schroder J, Wenz F, Schad LR, Baudendistel K, Knopp MV: Sensorimotor cortex and supplementary motor area changes in schizophrenia. A study with functional magnetic resonance imaging. Br J Psychiatry 1995;167:197-201.

172 O’Tuathaigh CM, Waddington JL: Mutant mouse models: phenotypic relationships to domains of psychopathology and pathobiology in schizophrenia. Schizophr Bull 2010;36:243-245.

173 van den Buuse M: Modeling the positive symptoms of schizophrenia in genetically modified mice: pharmacology and methodology aspects. Schizophr Bull 2010;36: 246-270.

174 Karl T, Duffy L, O’Brien E, Matsumoto I, Dedova I: Behavioural effects of chronic haloperidol and risperidone treatment in rats. Behav Brain Res 2006;171:286-294.

175 Waddington JL, Cross AJ, Gamble SJ, Bourne RC: Spontaneous orofacial dyskinesia and dopaminergic function in rats after 6 months of neuroleptic treatment. Science 1983;220:530-532.

176 Gunne LM, Haggstrom JE, Sjoquist B: Association with persistent neuroleptic-induced dyskinesia of regional changes in brain GABA synthesis. Nature 1984;309: 347-349.

177 Moore H, Jentsch JD, Ghajarnia M, Geyer MA, Grace AA: A neurobehavioral systems analysis of adult rats exposed to methylazoxymethanol acetate on e17: implications for the neuropathology of schizophrenia. Biol Psychiatry 2006;60:253-264.

178 Radyushkin K, El-Kordi A, Boretius S, Castaneda S, Ronnenberg A, Reim K, Bickeboller H, Frahm J, Brose N, Ehrenreich H: Complexin2 null mutation requires a 'second hit' for induction of phenotypic changes relevant to schizophrenia. Genes Brain Behav 2010;9:592-602.

179 Pioli EY, Meissner W, Sohr R, Gross CE, Bezard E, Bioulac BH: Differential behavioral effects of partial bilateral lesions of ventral tegmental area or substantia nigra pars compacta in rats. Neuroscience 2008; 153:1213-1224

180 Wadenberg ML, Soliman A, VanderSpek SC, Kapur S: Dopamine D(2) receptor occupancy is a common mechanism underlying animal models of antipsychotics and their clinical effects. Neuropsychopharmacology 2001;25:633-641.

181 Hauber W: Blockade of subthalamic dopamine D1 receptors elicits akinesia in rats. Neuroreport 1998;9:4115-4118.

182 Kornhuber J, Fischer EG: Glutamic acid diethyl ester induces catalepsy in rats. A new model for schizophrenia? Neurosci Lett 1982;34:325-329. 
183 Shiigi Y, Casey DE: Behavioral effects of ketamine, an NMDA glutamatergic antagonist, in non-human primates. Psychopharmacology (Berl) 1999;146:67-72.

184 Noda Y, Kamei H, Mamiya T, Furukawa H, Nabeshima T: Repeated phencyclidine treatment induces negative symptom-like behavior in forced swimming test in mice: imbalance of prefrontal serotonergic and dopaminergic functions. Neuropsychopharmacology 2000;23:375-387.

- 185 Noda Y, Yamada K, Furukawa H, Nabeshima T: Enhancement of immobility in a forced swimming test by subacute or repeated treatment with phencyclidine: a new model of schizophrenia. Br J Pharmacol 1995;116:2531-2537.

-186 Li Z, Boules M, Williams K, Gordillo A, Li $\mathrm{S}$, Richelson E: Similarities in the behavior and molecular deficits in the frontal cortex between the neurotensin receptor subtype 1 knockout mice and chronic phencyclidine-treated mice: relevance to schizophrenia. Neurobiol Dis 2010;40:467-477.

-187 O’Tuathaigh CM, Kirby BP, Moran PM, Waddington JL: Mutant mouse models: genotype-phenotype relationships to negative symptoms in schizophrenia. Schizophr Bull 2010;36:271-288.

-188 Schiffelholz T, Hinze-Selch D, Aldenhoff JB: Perinatal MK-801 treatment affects agerelated changes in locomotor activity from childhood to later adulthood in rats. Neurosci Lett 2004;360:157-160.

189 Fendt M, Lex A, Falkai P, Henn FA, Schmitt A: Behavioural alterations in rats following neonatal hypoxia and effects of clozapine: implications for schizophrenia. Pharmacopsychiatry 2008;41:138-145.

-190 Mooslehner KA, Chan PM, Xu W, Liu L, Smadja C, Humby T, Allen ND, Wilkinson LS, Emson PC: Mice with very low expression of the vesicular monoamine transporter 2 gene survive into adulthood: potential mouse model for parkinsonism. Mol Cell Biol 2001;21:5321-5331.

-191 Zhang M, Ballard ME, Basso AM, Bratcher N, Browman KE, Curzon P, Konno R, Meyer AH, Rueter LE: Behavioral characterization of a mutant mouse strain lacking Damino acid oxidase activity. Behav Brain Res 2011;217:81-87.

-192 Ortega-Alvaro A, Aracil-Fernandez A, Garcia-Gutierrez MS, Navarrete F, Manzanares J: Deletion of CB2 cannabinoid receptor induces schizophrenia-related behaviors in mice. Neuropsychopharmacology 2011;36:1489-1504.

193 Hattori S, Murotani T, Matsuzaki S, Ishizuka T, Kumamoto N, Takeda M, Tohyama M, Yamatodani A, Kunugi H, Hashimoto $\mathrm{R}$ : Behavioral abnormalities and dopamine reductions in sdy mutant mice with a deletion in Dtnbpl, a susceptibility gene for schizophrenia. Biochem Biophys Res Commun 2008;373:298-302.
194 Roy K, Murtie JC, El-Khodor BF, Edgar N, Sardi SP, Hooks BM, Benoit-Marand M, Chen C, Moore H, O’Donnell P, Brunner D, Corfas G: Loss of ERBB signaling in oligodendrocytes alters myelin and dopaminergic function, a potential mechanism for neuropsychiatric disorders. Proc Natl Acad Sci USA 2007;104:8131-8136.

195 Morello N, Bianchi FT, Marmiroli P, Tonoli E, Rodriguez Menendez V, Silengo L, Cavaletti G, Vercelli A, Altruda F, Tolosano $\mathrm{E}$ : A role for hemopexin in oligodendrocyte differentiation and myelin formation. PLoS One 2011;6:e20173.

196 Andreasen NC, Paradiso S, O’Leary DS: 'Cognitive dysmetria' as an integrative theory of schizophrenia: a dysfunction in cortical-subcortical-cerebellar circuitry? Schizophr Bull 1998;24:203-218.

197 Friston KJ: Schizophrenia and the disconnection hypothesis. Acta Psychiatr Scand Suppl 1999;395:68-79.

198 Haroutunian V, Davis KL: Introduction to the special section: myelin and oligodendrocyte abnormalities in schizophrenia. Int J Neuropsychopharmacol 2007;10:499_ 502.

199 Yang Y, Fung SJ, Rothwell A, Tianmei S, Weickert CS: Increased interstitial white matter neuron density in the dorsolateral prefrontal cortex of people with schizophrenia. Biol Psychiatry 2011;69:63-70.

200 Harrison PJ, Weinberger DR: Schizophrenia genes, gene expression, and neuropathology: on the matter of their convergence. Mol Psychiatry 2005;10:40-68, image 45 .

201 Connor CM, Guo Y, Akbarian S: Cingulate white matter neurons in schizophrenia and bipolar disorder. Biol Psychiatry 2009;66: 486-493.

202 Mei L, Xiong WC: Neuregulin 1 in neural development, synaptic plasticity and schizophrenia. Nat Rev Neurosci 2008;9: 437-452.

203 Hahn CG, Wang HY, Cho DS, Talbot K, Gur RE, Berrettini WH, Bakshi K, Kamins J, Borgmann-Winter KE, Siegel SJ, Gallop RJ, Arnold SE: Altered neuregulin 1-ERBB4 signaling contributes to NMDA receptor hypofunction in schizophrenia. Nat Med 2006;12:824-828.

204 Barakat A, Dean B, Scarr E, Evin G: Decreased neuregulin $1 \mathrm{C}$-terminal fragment in Brodmann's area 6 of patients with schizophrenia. Schizophr Res 2010;124: 200-207.

205 Lopez-Bendito G, Cautinat A, Sanchez JA, Bielle F, Flames N, Garratt AN, Talmage DA, Role LW, Charnay P, Marin O, Garel S: Tangential neuronal migration controls axon guidance: a role for neuregulin-1 in thalamocortical axon navigation. Cell 2006; 125:127-142.
206 Bai YM, Chou KH, Lin CP, Chen IY, Li CT, Yang KC, Chou YH, Su TP: White matter abnormalities in schizophrenia patients with tardive dyskinesia: a diffusion tensor image study. Schizophr Res 2009;109:167-181.

207 Douaud G, Mackay C, Andersson J, James S, Quested D, Ray MK, Connell J, Roberts N, Crow TJ, Matthews PM, Smith S, James A: Schizophrenia delays and alters maturation of the brain in adolescence. Brain 2009; 132:2437-2448.

208 Federspiel A, Begre S, Kiefer C, Schroth G, Strik WK, Dierks T: Alterations of white matter connectivity in first episode schizophrenia. Neurobiol Dis 2006;22:702-709.

-209 Kyriakopoulos M, Bargiotas T, Barker GJ, Frangou S: Diffusion tensor imaging in schizophrenia. Eur Psychiatry 2008;23: 255-273.

210 Schneiderman JS, Hazlett EA, Chu KW, Zhang J, Goodman CR, Newmark RE, Torosjan Y, Canfield EL, Entis J, Mitropoulou V, Tang CY, Friedman J, Buchsbaum MS: Brodmann area analysis of white matter anisotropy and age in schizophrenia. Schizophr Res 2011;130:57-67.

$>211$ Gogtay N, Lu A, Leow AD, Klunder AD, Lee AD, Chavez A, Greenstein D, Giedd JN, Toga AW, Rapoport JL, Thompson PM: Three-dimensional brain growth abnormalities in childhood-onset schizophrenia visualized by using tensor-based morphometry. Proc Natl Acad Sci USA 2008; 105:15979-15984

-212 Perez-Iglesias R, Tordesillas-Gutierrez D, McGuire PK, Barker GJ, Roiz-Santianez R, Mata I, de Lucas EM, Rodriguez-Sanchez JM, Ayesa-Arriola R, Vazquez-Barquero JL, Crespo-Facorro B: White matter integrity and cognitive impairment in first-episode psychosis. Am J Psychiatry 2010;167:451458.

213 Bracht T, Schnell S, Federspiel A, Jann K, Razavi N, Horn H, Wiest R, Dierks T, Müller TJ, Strik W, Walther S: Altered motor pathway integrity in schizophrenia: World Federation of Societies of Biological Psychiatry. Prague, WFSBP, 2011, pp P18-P25.

214 Knickmeyer RC, Gouttard S, Kang C, Evans D, Wilber K, Smith JK, Hamer RM, Lin W, Gerig G, Gilmore JH: A structural MRI study of human brain development from birth to 2 years. J Neurosci 2008;28:1217612182 .

215 Giedd JN, Rapoport JL: Structural MRI of pediatric brain development: what have we learned and where are we going? Neuron 2010;67:728-734.

216 Gogtay N, Giedd JN, Lusk L, Hayashi KM, Greenstein D, Vaituzis AC, Nugent TF 3rd, Herman DH, Clasen LS, Toga AW, Rapoport JL, Thompson PM: Dynamic mapping of human cortical development during childhood through early adulthood. Proc Natl Acad Sci USA 2004;101: 8174-8179. 
-217 Zielinski BA, Gennatas ED, Zhou J, Seeley WW: Network-level structural covariance in the developing brain. Proc Natl Acad Sci USA 2010;107:18191-18196

-218 Paus T, Zijdenbos A, Worsley K, Collins DL, Blumenthal J, Giedd JN, Rapoport JL, Evans AC: Structural maturation of neural pathways in children and adolescents: in vivo study. Science 1999;283:1908-1911.

-219 Barnea-Goraly N, Menon V, Eckert M, Tamm L, Bammer R, Karchemskiy A, Dant CC, Reiss AL: White matter development during childhood and adolescence: a crosssectional diffusion tensor imaging study. Cereb Cortex 2005;15:1848-1854.

-220 Waddington JL, Buckley PF, Scully PJ, Lane A, O’Callaghan E, Larkin C: Course of psychopathology, cognition and neurobiological abnormality in schizophrenia: developmental origins and amelioration by antipsychotics? J Psychiatr Res 1998;32: 179-189.

-221 Weinberger DR: From neuropathology to neurodevelopment. Lancet 1995;346:552557.

-222 Peralta V, Cuesta MJ, Serrano JF: Obstetric complications and neurological abnormalities in neuroleptic-naive psychotic patients. Eur Arch Psychiatry Clin Neurosci 2006; 256:407-413.

-223 Brown AS, Vinogradov S, Kremen WS, Poole JH, Bao Y, Kern D, McKeague IW: Association of maternal genital and reproductive infections with verbal memory and motor deficits in adult schizophrenia. Psychiatry Res 2011;188:179-186.

-224 Jones P, Rodgers B, Murray R, Marmot M: Child development risk factors for adult schizophrenia in the British 1946 birth cohort. Lancet 1994;344:1398-1402.

-225 Isohanni M, Jones PB, Moilanen K, Rantakallio P, Veijola J, Oja H, Koiranen M, Jokelainen J, Croudace T, Jarvelin M: Early developmental milestones in adult schizophrenia and other psychoses. A 31-year follow-up of the Northern Finland 1966 Birth Cohort. Schizophr Res 2001;52:1-19.
226 Cannon M, Caspi A, Moffitt TE, Harrington $\mathrm{H}$, Taylor A, Murray RM, Poulton R: Evidence for early-childhood, pan-developmental impairment specific to schizophreniform disorder: results from a longitudinal birth cohort. Arch Gen Psychiatry 2002;59:449-456.

227 Rosso IM, Bearden CE, Hollister JM, Gasperoni TL, Sanchez LE, Hadley T, Cannon TD: Childhood neuromotor dysfunction in schizophrenia patients and their unaffected siblings: a prospective cohort study. Schizophr Bull 2000;26:367-378.

228 Clarke MC, Tanskanen A, Huttunen M Leon DA, Murray RM, Jones PB, Cannon $\mathrm{M}$ : Increased risk of schizophrenia from additive interaction between infant motor developmental delay and obstetric complications: evidence from a population-based longitudinal study. Am J Psychiatry 2011; 168:1295-1302.

229 Schiffman J, Sorensen HJ, Maeda J, Mortensen EL, Victoroff J, Hayashi K, Michelsen NM, Ekstrom M, Mednick S: Childhood motor coordination and adult schizophrenia spectrum disorders. Am J Psychiatry 2009;166:1041-1047.

230 Walker EF, Savoie T, Davis D: Neuromotor precursors of schizophrenia. Schizophr Bull 1994;20:441-451.

231 Mittal VA, Tessner KD, Trottman HD, Esterberg M, Dhrub SH, Simeonova DI, McMillan AL, Murphy E, Saczawa ME, Walker EF: Movement abnormalities and the progression of prodromal symptomatology in adolescents at risk for psychotic disorders. J Abnorm Psychol 2007;116:260-267.

232 Torrey EF, Taylor EH, Bracha HS, Bowler AE, McNeil TF, Rawlings RR, Quinn PO, Bigelow LB, Rickler K, Sjostrom K, et al: Prenatal origin of schizophrenia in a subgroup of discordant monozygotic twins. Schizophr Bull 1994;20:423-432.

233 Penzes P, Cahill ME, Jones KA, VanLeeuwen JE, Woolfrey KM: Dendritic spine pathology in neuropsychiatric disorders. Nat Neurosci 2011;14:285-293.

234 Ridler K, Veijola JM, Tanskanen P, Miettunen J, Chitnis X, Suckling J, Murray GK, Haapea M, Jones PB, Isohanni MK, Bullmore ET: Fronto-cerebellar systems are associated with infant motor and adult executive functions in healthy adults but not in schizophrenia. Proc Natl Acad Sci USA 2006;103:15651-15656.
235 Neelam K, Garg D, Marshall M: A systematic review and meta-analysis of neurological soft signs in relatives of people with schizophrenia. BMC Psychiatry 2011;11: 139.

236 Mittal VA, Walker EF: Movement abnormalities predict conversion to axis I psychosis among prodromal adolescents. J Abnorm Psychol 2007;116:796-803.

237 Hutton S, Kennard C: Oculomotor abnormalities in schizophrenia: a critical review. Neurology 1998;50:604-609.

-238 Strik WK, Dierks T, Boning J, Osterheider M, Caspari A, Korber J: Disorders of smooth pursuit eye movement and auditory N100 in schizophrenic patients. Psychiatry Res 1992;41:227-235.

239 Park S, Matthews N, Gibson C: Imitation, simulation, and schizophrenia. Schizophr Bull 2008;34:698-707.

240 Aubin G, Stip E, Gelinas I, Rainville C, Chapparo C: Daily activities, cognition and community functioning in persons with schizophrenia. Schizophr Res 2009;107: 313-318.

241 Cannizzaro MS, Cohen H, Rappard F, Snyder PJ: Bradyphrenia and bradykinesia both contribute to altered speech in schizophrenia: a quantitative acoustic study. Cogn Behav Neurol 2005;18:206-210.

242 Horn H, Federspiel A, Wirth M, Muller TJ, Wiest R, Wang JJ, Strik W: Structural and metabolic changes in language areas linked to formal thought disorder. Br J Psychiatry 2009;194:130-138.

243 Kerns JG: Verbal communication impairments and cognitive control components in people with schizophrenia. J Abnorm Psychol 2007;116:279-289.

244 Bach DR, Herdener M, Grandjean D, Sander D, Seifritz E, Strik WK: Altered lateralisation of emotional prosody processing in schizophrenia. Schizophr Res 2009;110: 180-187.

245 Kring AM, Moran EK: Emotional response deficits in schizophrenia: insights from affective science. Schizophr Bull 2008;34: 819-834. 